\title{
Tanítói narratívák a Család és Iskola címú folyóiratban
}

\author{
SzÜCs KatAlin
}

ELTE

\begin{abstract}
A dualizmuskori pedagógiai sajtó termékei gazdag forrásanyagot jelentenek a pedagógiatörténeti kutatások számára. A pedagógiai szaklapok betekintést engednek az oktatásügy formálódásával kapcsolatos fontosabb témákba és a pedagógushivatás különböző formáihoz kötődő professzionalizációs folyamatokba. A Család és Iskola címú kolozsvári folyóirat 1875-ben indult útjára, elsődleges célja a pedagógusi szakmai csoportok professzionalizációs és szakmásodási folyamatainak a segítése volt. Jelen tanulmányban a lap Paedagogiai Esetek címú rovatának írásait vizsgálom az 1889 és 1900 közötti időszakban. Célom annak a feltárása, hogy a pedagógiai gondolkodást milyen formában, milyen eszközökkel alakítják ezek a gyakran a szóbeliség jellemzőit tükröző szövegek, a hétköznapi iskolai helyzetekhez kötődő tanítói narratívák. Kutatásom során a minőségi elemzés különböző fajtáinak (leíró és értelmező elemzés) segítségével dolgozom fel a tanítói narratívákat. A szövegek elemzéséhez a narrativitás elméletei szolgáltatják az elméleti hátteret.

Kulcsszavak: népoktatás, professzionalizáció, narratíva, kollektív emlékezet
\end{abstract}

\section{A DUALIZMUSKORI PEDAGÓGIAI SAJTÓ}

A dualizmuskori pedagógiai sajtó termékei gazdag és különböző kutatási irányoknak teret engedő forrást jelentenek a pedagógiatörténeti kutatók számára. A különféle múfajú és témájú szövegekben bővelkedő szaksajtó kiterjedt információanyaga szélesíti a rálátásunkat mind a neveléstudomány, mind az oktatáspolitika korabeli aktualitásaira. Segítségével részesei lehetünk az oktatásügy formálódásával kapcsolatos diskurzusnak, betekinthetünk a pedagógushivatás különböző formáihoz kötődő professzionalizációs folyamatokba; tanúi lehetünk olyan új kezdeményezések megjelenésének és megszilárdulásának, mint a gyermektanulmányi, a reformpedagógiai szemléletmód.

A korszakban megjelenő sajtótermékek szerepe a tágabb pedagógia- és társadalomtörténeti kontextus ismeretében értelmezhető igazán. A dualizmus kora a népoktatás expanziójának az időszaka volt. Az 1868. évi népoktatási törvény, ami bevezette a tankötelezettséget a hat és tizenkét év közötti gyermekek 
számára, szükségszerúen megkövetelte a tanítók számának növekedését is.A népoktatási törvény elvárásokat támasztott a tanítóképzés színvonalát, illetve a tanítók szakmai felkészültségének szintjét illetően is. Elvárásként jelentek meg a tanítókkal szemben az értelmiségi létet kísérő olyan tevékenységek, mint a folyamatos múvelődés, az egyleti tevékenység, az önképzés. "A néptanítói hivatás szakmai erősödése és a népoktatás szervezeti és tartalmi modernizációja együtt járt" (Szabolcs, 2011. 79. o.). A modern tanítói hivatás - melyet a közoktatás dualizmuskori modernizációja teremtett meg - egyik legfontosabb eleme lett a folyamatos szakmai megújulás igénye és lehetősége(Szabolcs, 2011. 79-81. o.; vö. Baska, Nagy és Szabolcs, 2001; Kelemen, 2002, 2007; Németh, 2008, 2013).

A modern közoktatás törvényi szabályozásával párhuzamosan egyre inkább előtérbe került a pedagógiai sajtó informáló és véleményformáló hatása, mely fontos szerepet játszott abban, hogy a gyermeknevelés és iskoláztatás kérdéseit továbbítsa a szakmabeliekhez és a laikus közvéleményhez is (Szabolcs, 2011. 13. o.). A jelzett időszakban megjelenő pedagógiai szaklapokra egyfajta tájékoztató funkció megvalósítása volt tehát jellemző, legyen szó akár a pedagógiai területen dolgozók érdekvédelméről, akár az új pedagógiai, pszichológiai nézetekről és az azok nyomán kibontakozó módszertani ajánlásokról. A nagyobb hatókörrel rendelkező, az ország szinte egész területén megjelenő és hosszabb időszakon keresztül múködő folyóiratok a szakmai tudásmegosztás, tudásátadás, pedagógiai gondolkodás formálásának fórumává váltak (részletesen ld. Baranyai és Keleti, 1937). A pedagógia egyes részterületei „kitermelték” a saját érdeklődési körükhöz tartozó lapjaikat (pl. Kisdednevelés, Néptanítók Lapja), majd adott problématerületekre koncentráló tematikus folyóiratok is indultak (pl. Család és Iskola).

A pedagógiai szaksajtó forrásként való felhasználásában jelentős szerepe volt Szabolcs Évának, aki metodikailag is új eljárásokat alkalmazva vizsgálta a sajtótermékek széles körét. Érdeklődésének a fókuszában - többek között - a gyermekről való gondolkodás és tudás differenciálódási folyamatának, a gyermektanulmányi és reformpedagógiai szemléletmód hazai, pedagógiai kultúrába való beépülésének, a néptanítók életvilágának a kutatása állt (Szabolcs és Mann, 1997; Szabolcs, 1999; Szabolcs, 2002; Szabolcs, 2003; Szabolcs és Hegedüs, 2008; Szabolcs, 2009; Szabolcs, 2011).

A tanítói életpálya, a szakmai identitásformálódás folyamatának leírására fókuszált Baska Gabriella is több kutatásában (Baska, 1998; Baska, Nagy és Szabolcs, 2001; Baska, 2011). A téma újszerú megközelítését jelzi, hogy a szerző a szaksajtón túl a tanítóság dualizmuskori hírlapi reprezentációjának egy sajátos szeletét is vizsgálat alá vette, amikor a Borsszem Jankó címú vicclap szövegeit használta forrásként (Baska, 2018). Én magam a tanítói identitásteremtés mikrofolyamatait egy egészen speciális szövegkorpusz, a tanítói nekrológok elemzésén keresztül ragadtam meg (Szücs, 2012).

A gyermekkép konstruálódásával és az apaszerep változásaival több ízben foglalkozott Pukánszky Béla (Pukánszky, 1999, 2001, 2002). A család és az 
iskola közötti kapcsolat tanulmányozása visszatérő motívuma Nóbik Attila kutatásainak is. Ezen kutatások a szaksajtó nyújtotta gazdag forrásanyagot különböző aspektusokból értelmezik; a családi és iskolai nevelés kapcsolódása mellett megjelenik a pedagógiai közélet szaklapok által tükrözött jellemzőinek vizsgálata is, illetve a néptanítói szakma feminizációjának a feltárása (Nóbik 2002, 2014, 2019). A tanítónői életutak vizsgálatával Hegedús Judit foglalkozott (Hegedüs, 2003).

Szabolcs Éva és Baska Gabriella mellett Pirka Veronika is az életreform motívumok pedagógiai sajtóban való megjelenését vizsgálta (Baska és Szabolcs, 2005; Pirka, 2010).

Jól látható, hogy az elmúlt két évtizedben a dualizmuskori pedagógiai sajtó vizsgálata nagyobb kutatói érdeklődésre tartott számot. Történt ez annak ellenére, hogy a sajtóforrásokkal dolgozó kutatónak fontos kutatásmódszertani megfontolásokat is figyelembe kell venni e szövegtípus forrásértékének korlátai kapcsán. A szaklapokban megjelentetett szövegek elsősorban a nevelés, oktatás területén dolgozók tapasztalatait, nézeteit jelenítették meg, melyeknek még egy adott szakmai közösség (szerkesztőbizottság) szûrőjén is át kellett haladniuk, mielőtt kikerültek a nyilvános térbe, az újságok hasábjaira. A megjelent írások sok információt hordoznak az oktatás, nevelés folyamatában érintettekről, ezen információk azonban elsősorban a szerzők mentalitását tükrözik, azok narratíváit közvetítik (vö. Nóbik, 2002; Szabolcs, 2011). Ettől függetlenül a pedagógiai sajtókutatás a körültekintő kutatásmódszertani eljárások alkalmazása mellett értékes adatokkal szolgál, különösen igaz ez a dualizmuskori folyóiratokra, melyek erőteljes szerepet játszottak az ismeretközvetítésben, a szakmabeliek közötti kapcsolat megteremtésében.

Széles a spektruma a szaklapok azon eszköztárának, mely a pedagógiai kultúra alakításához, fejlesztéséhez, fenntartásához járult hozzá. Jelen tanulmányban a Család és Iskola címú folyóirat Paedagogiai Esetek ${ }^{1}$ címú rovatának írásait vizsgálom az 1889 és 1900 közötti időszakban. A folyóirat és a Paedagogiai Esetek szövegkorpuszának vizsgálatával már több, a korszak iránt érdeklődő kutató is foglalkozott (ld. pl. Nóbik, 2002, 2014; Szabolcs, 2002), tekintve, hogy az 1875 és 1919 között megjelenő Család és Iskola a dualizmuskori szaksajtó egyik reprezentáns példányának nevezhető. Jelen tanulmányban a tanítók tollából származó történetek elemzése során főként a szövegek formai, strukturális sajátosságaira és részben a tartalmi jellemzőkre fókuszálva a narratíva mint múfaj pedagógiai kommunikációban betöltött funkcióját vizsgálom. Célom annak a feltárása, hogy a pedagógiai gondolkodást milyen hatásmechanizmusok mentén alakíthatták ezek a gyakran a szóbeliség jellemzőit tükröző szövegek, a hétköznapi iskolai helyzetekhez kötődő tanítói történetek. Kutatásom során a minőségi elemzés különböző fajtáinak (leíró és értelmező elemzés) segítségével

\footnotetext{
${ }^{1}$ A Paedagogiai Esetek rovat neve, és a folyóiratból szó szerint idézett részletek a korszak helyesírási viszonyait tükrözik.
} 
dolgozom fel a szövegeket. Munkám elméleti hátterét a narrativitás elméletei szolgáltatják.

Tanulmányomban elsőként röviden összegzem a Család és Iskola címú folyóirat fóbb jellemzőit, és ismertetem a Paedagogiai Esetek rovat múködésével kapcsolatos fontosabb tudnivalókat. Részletesebben tárgyalom a narratíva, narrativitás fogalmával kapcsolatos elméleteket, bemutatva így azt az értelmezési keretet, melyet segítségül hívok a tanítói történetek szakmásodásban betöltött szerepének leírása során. Végül összegzem a vizsgált szövegkorpusz főbb formai és strukturális jellemzőit, és ezek összefüggései nyomán értelmezem a Paedagogiai Esetek gondolkodásformáló szerepét.

\section{A CSAlÁd És IsKOLA A „SZAKMÁSOdÁs SZOLGÁlATÁbAN”}

Mint bevezetőmben említettem, a közoktatás dualizmuskori modernizációjával párhuzamosan megindultak a pedagógushivatás különböző formáihoz kötődő professzionalizációs folyamatok is. A néptanítóság szakmai erősödésének feltétele volt a szakmai megújulás, a néptanítói tudástartalom gazdagodása (Baska, Nagy és Szabolcs, 2001; Kelemen, 2002, 2007; Németh, 2008, 2013; Szabolcs, 2011). A néptanítók szakmásodási ${ }^{2}$ folyamata azonban sok szempontból belső feszültségektől volt terhes. A tanítók szakmai érdekérvényesítő képessége igen csekély volt a korszakban; alacsony társadalmi és anyagi elismertségük, rossz munkaés életkörülményeik állandó viták tárgyát képezték (Baska, Nagy és Szabolcs 2001; Kelemen, 2002; Szabolcs, 2011) ${ }^{3}$. Kelemen Elemér rámutat, hogy az értelmiségi lét perifériájára szorított tanítók nagy része képtelen volt megfelelni a velük szemben támasztott, egyre növekvő szakmai igényeknek, követelményeknek. A tanítóhiány, a nem megfelelő szakképzettség és a tanítók kiszolgáltatott anyagi helyzete a mindennapi, tantermi munka rovására ment (Kelemen, 2002. 25-26. o.).

A viszontagságos körülmények ellenében a néptanítóság szakmai erősödését szolgálták a tanítóképző intézetek, "melyek az intézményi keretet szolgáltatták a néptanítói tudás kanonizációs folyamataihoz" (Nóbik, 2014. 191. o.), a modern néptanítói tudást reprezentáló, tanítóképzésben használt tankönyvek; és az Elemi

\footnotetext{
${ }^{2}$ „A 19. század második felében megjelenő két tipikus pedagógusi szakmai csoport (a népiskolák tanítói és a felsőbb iskolák tanárai) szakmásodási és professziós folyamatai során két, szervesen és funkcionálisan kifejlődő, ugyanakkor egymástól számos lényeges vonásában eltérő tanári, valamint tanítói pedagógiai szakmai kultúra és pedagógusi szaktudás jön létre." (Németh, 2013. 101. o.). Ennek nyomán választjuk szét a professzionalizáció és a szakmásodás fogalmát. Míg előbbit kifejezetten a szakértői vagy tudáselit (középiskolai/gimnáziumi tanár típusú, illetve oktatáspolitikai és tanügyigazgatási elit) egyetemen megszerezhető tudásának konstrukciós és intézményesülési folyamataira értjük; addig a szakmásodás fogalmát az alacsonyabb végzettséget igénylő, alacsonyabb társadalmi presztízsû szakmák, esetünkben a néptanítói szakma intézményesülési folyamataihoz kötjük (Németh, 2013. 101.o., továbbá Németh, 2005, 2007, 2012; Nóbik, 2014).

${ }^{3}$ Hogy a lapokban a tanítók által sugallt rossz anyagi helyzet mennyire felelt meg a valóságnak, azzal kapcsolatban Pethő László Tanítók és a társadalom c. 1991-es kötetében nyitott meg egyfajta diskurzust (Pethő, 1991; ugyanezzel kapcsolatban ld. még Baska, 2018).
} 
Néptanítók Enciklopédiája is modern tudásbázisként funkcionált (Pukánszky, 2005; Nóbik, 2006, 2014; Németh, 2008). A fejlődés mellett elkötelezett, oktatásüggyel foglalkozók és néptanítók közremúködésével hivatalosan vagy olykor spontán módon és informálisan megalakultak olyan társulatok, szervezetek is, melyek egyfajta szellemi múhelyként múködtek, és állandó vagy időszakos kiadványaikkal (folyóiratok, évkönyvek, egyleti kiadványok stb.) a szakmai fejlődést facilitálták (Kelemen, 2002. 28. o.; Nóbik, 2014. 191. o.).

A pedagógiai sajtótermékek is erőteljes támogató hátteret nyújtottak a szakmai megújuláshoz és a pedagógiai tudás bővítéséhez. A néptanítók szakmásodási folyamatait elősegítendő indult - többek között - útjára 1875-ben a Család és Iskola (Nevelés és oktatásügyi szakközlöny, szülők, kisdednevelők, tanítók és a nevelésügy barátai számára) címú kolozsvári folyóirat, melyet a KolozsDoboka megyei tanítóegyesület adott ki. Az 1918-ig megjelenő Család és Iskola Erdély legjelentősebb nevelésügyi folyóirata volt, a dualizmuskori szaksajtó egyik reprezentáns képviselője (Nóbik, 2014. 195. o.).

A kéthetente megjelenő lap állandó rovatokban foglalkozott a tanítóképzés nehézségeivel, a tanítók gyakorlati munkája során felmerülő problematikus helyzetekkel. A Család és Iskola célja a tanítóság szakmai támogatása volt, ezért segíto, mindeközben építő kritikai attitûddel kezelte a tanítók képzésével kapcsolatos nehézségeket, és reflektált a pedagógusok hiányos szaktárgyi ismereteire, módszertani felkészületlenségük kérdéseire. Ennek nyomán óratervjavaslatokat, módszertani útmutatókat és neveléslélektani jelenségekkel foglalkozó cikkeket, esettanulmányokat is közölt a szaklap. A szerkesztőség egyik kiemelt „,küldetése" volt, hogy segítse az iskola és a szülői ház közötti szorosabb kapcsolat kiépítését, támogatva ezzel a hatékony nevelés és oktatás megvalósulását. Jellemző volt még a neveléstudomány újszerú elgondolásainak a közvetítése is; az oktatáspolitika változásainak nyomon követése, illetve az azokra való reflektálás, a szakmai közösséghez tartozók érdekvédelme, küzdelem a tanítóság életés munkakörülményeinek előremozdításáért. A szerkesztőbizottság egy igen fontos célkitûzése volt, hogy „a szükséges és okszerü reformok életbeléptetéséért fog buzgólkodni" (Szerkesztôségi közlemény, 1875. 1. o.), segítve ezzel a népoktatás szakmai színvonalának emelését.

A lap tematikájának a szerves részét képezte a Paedagogiai Esetek címú rovat is, mely a pedagógusok által beküldött, mindennapos nevelési helyzetekkel kapcsolatos konfliktusok tárháza volt. A kutatás során az 1889 és 1900 között megjelent esetekre (322 darab) fókuszáltam, ebben az időszakban az akkor már hosszú évek óta rendszeresen megjelenő lap egyre inkább tükrözte azokat a sokasodó problémákat, amelyek az általános tankötelezettség elfogadása nyomán az iskolarendszerbe belépő gyermekek számának növekedéséből adódtak.

Baló József, a rovat szerkesztője a következőképpen gondolkodott a szövegek gyakorlati hasznáról az Egy kis elmélet a paedagogiai esetek gyújtéséhez címú írásában: "Rovatunk nagyon gyakorlati irányú és értékü, azért pótol hézagot, azért oly becses. A mily megbecsülhetetlen szolgálatot tesznek az emberrel morális tekintetekből 
foglalkozók a bünügyi statisztika adatai, ép olyan fontosakkal járulnak majd a paedagogiai esetek a nevelés sikeréhez, a gyakorlati nevelés elméletének megírásához" ${ }^{4}$ (Baló, 1889. 153-154. о.).

Baló pedagógiai hitvallása szerint a nevelők feladata a szerető családi körből kikerülő gyermek megóvása, illetve a társdalomba való belépésre való felkészítése volt. A gyermekre kis emberként, az iskolára kis társadalomként tekintett. Az iskolai élet „bonyolult” múködési mechanizmusai során a nevelő munkájának gondolta a gyermek minél alaposabb megismerését, a tanítók személyes és szakmai önismeretének a fejlesztését, a körültekintő nevelői tevékenykedés megvalósítását. Mentalitását jól érzékelteti a következő szövegrészlet: „Számítsuk még ezekhez azt is, hogy a nevelöi ténykedés mindig relativ értékú s attól függ, hogy milyen a nevelendö egyén, mi az épen specialiter felmerült eset, mi az elözménye. A nevelöi ténykedés helyességét az dönti el, hogy ismert elözmények után valamely örvendetes következmény épen az egészen tárgyilagosan nézett nevelöi eljárás eredménye-e? Ily szempontok figyelembevételével, a multtal való folytonos összeköttetésben kell a nevelönek eljárnia (...) paedagogiai eseteket kíváló haszonnal úgy gyüjthetünk, ha az egyénnek multját, körülményeit, egyéni vonásait, gyarlósága mellett talán kiválóságait is ismerjük (...) ne csupán az életböl kiszakitott darabokat ohajtsunk látni, hanem meglesni egy darab életet, mint van az a multhoz és jövőhöz kötve" (Baló, 1889. 153-154. o.). Gyakorlati pedagógiáról való gondolkodása azt tükrözi, hogy alapvetően történetekben gondolkodott a nevelés hétköznapi eseményeivel kapcsolatosan, és a gyermekek fejlődését is a maga folytonosságában látta, nem puszta tényekre lecsupaszított, egymástól elszigetelt pedagógiai jelenségeket kívánt vizsgálni és közreadni, hanem a hétköznapok narratíváit szerette volna oly módon egységbe kovácsolni, hogy azokra, mint egy összefüggő neveléselméletre tekinthessenek az olvasók - ezt közvetítik szerkesztői ambíciói: „A Paedagogiai Esetek-et a magyar nevelésre olyan organumnak képzelem, mint a minő a Magyar Nyelvör a magyar nyelvre, s a Magyar tört. Életrajzok a magyar történelemre nézve." (Baló, 1890. 7. o.).

Baló elképzelése szerint, a sokrétú információkat és a gyermekről szerzett tapasztalatokat összegző esetek kiadásról kiadásra megjelentek az újságban, mind szerkezetükben, mind nyelvezetükben elkülönülve a lap egyéb írásaitól. A sokszor az élőbeszéd jegyeit is magukon viselő szövegek többnyire anekdoták, hétköznapi beszélgetések, szituációk elbeszélésének,illetve egy-egy problematikus helyzet kapcsán a nevelői önreflexió kihangosításának az érzetét keltették. Felmerül a kérdés, hogy a Család és Iskola különféle neveléstudományi és oktatáspolitikai problémákat körüljáró, logikusan felépülő érvrendszeren alapuló cikkeitől eltérő, a nevelők által közreadott, hétköznapi elbeszélésként értelmezhetố írások milyen módon segítették a tanítókat a munkájukban. E szövegek képesek voltak a tanítók gondolkodásának a formálására? Ha valóban volt gondolkodásformáló hatásuk, akkor milyen múködési mechanizmus állhatott ennek

\footnotetext{
${ }^{4}$ A Paedagogiai Esetek rovat neve és a folyóiratból szó szerint idézett részletek a korszak helyesírási viszonyait tükrözik.
} 
a hátterében? Ahhoz, hogy ezekre a kérdésekre választ kapjunk, illetve a szövegek társadalmi és szakmai életben esetlegesen betöltött szerepét felfejtsük, a narrativitás és a kollektív emlékezet szerveződésével kapcsolatos elméletalkotók munkáit hívom segítségül.

\section{A PAEdagogiai EseteK A NARRATÍv SZEMLÉLET TÜKRÉBEN}

\section{Kutatásmódszertani megfontolások}

A narratíva, narrativitás gyakran használt fogalmak a társadalomtudományi kutatásokban, értelmezésük széles jelentéstartományban mozog. A narratív megközelítés értelmezési lehetőségeinek sokféleségét jól tükrözi a Narratívák címú könyvsorozat is ${ }^{5}$, mely egyszerre mutatja meg a társadalomtudományi diszciplinák sajátos viszonyulását a narrativitás elméleti és kutatásmódszertani kérdéseihez; és mutat rá a narratív szemlélet interdiszciplináris jellegére. Az elbeszéléskutatás az irodalomtudományi kutatások terepéről kilépve mára már olyan tudományágakban is alapvető fontosságú, mint a pszichológia, a kulturális antropológia vagy a történettudomány. A kultúra narratívái címú kötet bevezetőjében N. Kovács Tímea (1999. 7. o.) felhívja a figyelmet arra, hogy míg korábban a narratívák a társadalomtudományok forrásait jelentették elsősorban (ld. pl. mítoszkutatás, élettörténetek feldolgozása), mára a narratív szemlélet azon iránya, értelmezése is megerősödött, mely a kulturális reprezentáció problémájára mutat rá olyan tudományterületek esetében, mint például a történettudomány vagy az etnográfia (White, 1975; Bruner, 1989). A történetírás posztmodern korszaka a nyelvi fordulat fogalmával kapcsolatosan irányította rá újra a figyelmet a narrativitás értelmezésére (N. Kovács, 1999. 8. o.; Szabolcs, 2016. 79. o.). A „linguistic turn” kontextusában merültek fel azok a kérdések, amelyek e tudományterületek önértelmezését alakítják. A nyelvi fordulat világított rá arra, hogy a nyelv nem pusztán a közvetítője, tükrözője a valóságnak; nem valami rajta kíviul álló valóságot ír le. A nyelv hozza létre, generálja a valóságot; a nyelvi kifejezés maga a megalkotott valóság. A történeti kutatás eredménye is egy nyelvi kompozíció, amelyben a kiválasztott nyelvi eszközök nem pusztán stiláris jelentőségúek, hanem hordozzák a történetkutatás lényegét. E nézőpont szerint a múltat kutató történész által létrehozott tudományos szöveg, értekezés maga is narratíva, egy megalkotott, lehetséges olvasata a múltnak (White, 1997; Gyáni, 2000; idézi: Szabolcs, 2016. 80. o.). Emellett továbbra is találkozunk azon értelmezéssel, amely szerint az olyan személyes források, visszaemlékezések, amiket a történész kutat, maguk is narratívának, elbeszélésnek tekinthetők. Ez esetben több idősík ötvöződik a forrást jelentő elbeszélésben: az első a visszaemlékezésben megjelenő múlt, a második a visszaemlékezés ideje, a harmadik idősík

\footnotetext{
${ }^{5}$ A Pécsi Tudományegyetem Narratív Kutatócsoportjának keretein belül készül a Narratívák c. tanulmánykötet-sorozat, melynek sorozatszerkesztője Thomka Beáta.
} 
pedig a forrásokat feldolgozó kutató által létrehozott narratíva ideje (Szabolcs, 2016. 80. o.).

A hazai pedagógiatörténeti kutatások is beépítik elméleti és kutatásmódszertani bázisukba a narratív szemléletet eltérő értelmezések mentén. Szabolcs Éva felhívja a figyelmet a narratív kutatás ernyőfogalomként (Fulda, 2014; idézi: Szabolcs, 2016) való értelmezésére, mely jelzi, hogy számos kutatásmódszertani megközelítés lehetősége adott annak a kutatónak, aki a narratív szemlélet jegyében vizsgálódik (ld. pl. Golnhofer és Szabolcs, 2009; Kolosai, 2013; Méreg, 2013).

Jelen tanulmányban a pedagógiai esetek makroszintư elemzésével kapcsolatos eredményeimet mutatom be a narratív szemlélet tükrében. Az összes megjelent és vizsgálat alá vett pedagógiai esetet (322 darab) egy összefüggő szövegkorpuszként kezeltem az elemzés során (vö. Szabolcs, 2011). Ezen álláspontomat erősítette meg az is, hogy maga a rovat szerkesztője is úgy tekintett a Paedagogiai Esetekre, mint összefüggő „,neveléstanra”, tekintve, hogy az egyes szövegek azonos cél mentén íródtak. A makroszintú elemzés során a szövegkorpusz főbb formai és tartalmi sajátosságait vettem vizsgálat alá. Elsősorban arra kerestem a választ a narratív szemlélet jegyében, hogy milyen jellemzők alapján szerveződnek egy nagy egységbe a személyes tanítói történetek, milyen stiláris, retorikai megoldásokra épít ez a nyilvános, szakmai térbe kihelyezett „szöveggyújtemény”. Másrészről, kíváncsi voltam arra is, hogy a narratíva, az elbeszélés mint múfaj milyen hatásmechanizmusok révén fejthetett ki hatást az olvasókra. Ahhoz, hogy e szövegek tényleges hatásairól beszéljünk, elengedhetetlen a szövegek mikroszintú elemzése is. Kutatásom jövőbeni irányait ez határozza meg.

A Paedagogiai Esetek szövegkorpuszának vizsgálatakor Jerome Bruner narratív és paradigmatikus gondolkodás ismeretelméleti különbségére felhívó elméletét és egy, a csoportos és nyilvános kommunikáció természetével foglalkozó kutató, Walter Fisher narrativitást mint kommunikációs magatartást, viszonyulást tárgyaló elméletét alkalmaztam értelmezési keretként.

\section{Elméletek a narrativitásról - az értelmezés keretei}

Jerome Bruner elmélete a gondolkodás két fő módját különbözteti meg, a narratívot és a paradigmatikust. A narratív képzelet alkotja meg a történeteket és az események történeti leírásait, míg a paradigmatikus vagy teoretikus gondolkodás a logikai igazságot kutatja. Értelmezésében a narratív gondolkodás olyan reprezentációs folyamat, automatikus modelláló eszköz, amely a tapasztalatok (események, személyek, cselekvések stb.) orális-verbális kommentárjait hozza létre. Bruner úgy gondolta, hogy a narratív készség a nyelvhasználat, különösen a beszéd mögött álló alapvető hajtóerő. Ez a késztetés meghatározza és formálja az egyén világlátását és a csoportét, közösségét is, amelyiknek a tagja. A csoportos narratív készségek vezetnek a valóság kollektív verziójához. A beszéd 
többnyire szabadon, narratív, elbeszélő módban folyik adott közösségeken belül, eközben folyamatosan teremtődik meg az újabb események kollektív verziója. Az elbeszélő mód legfőbb terméke a mítosz, ami a múlt összefüggő történeti rekonstrukcióját jelenti. A mítosz az elme eredeti, alapvető, integratív eszköze, különféle eseményeket igyekszik egy időbeli és okozati keretbe integrálni. A mítosz a nagyszámú epizódok összefúzését jelenti, helyet és jelentést ad azoknak a kisebb léptékú eseményeknek, amiket a mítosz felölel, egyfajta egységesítő gondolkodást megvalósítva így (Bruner, 1986; idézi: Donald, 2001. 192-196. o.). Bruner a narratív készséget inkább a gondolkodás egyik formájaként sorolta be, mint a nyelv egy aspektusaként (Bruner, 1986; idézi: Donald, 2001. 228. o.). Ezzel ellentétben a paradigmatikus gondolkodás szakít az orális-mitikus kultúra metaforikus stílusú jelentéseivel. A tudományos gondolkodás nem ilyen formában dolgozza fel az emberi élet során tapasztaltakat. Ahelyett, hogy az eseményeket jelentéssel való megtöltésük révén modellálná és analógia révén összekapcsolná, az elméletalkotás során részekre bont, elemez, törvényeket és szabályokat fogalmaz meg, elveket és taxonómiákat állít fel. Ezen gondolkodásfajta legmagasabb terméke és kormányzó konstruktuma a formális elmélet, ami integratív eszközként a gondolkodás és érvelés olyan rendszerét hozza létre, ami megjósol és magyarázatot ad (Bruner, 1986; idézi: Donald, 2001. 242-245. o.).

Walter Fisher szerint az „ember mesemondó állat”, mondhatni alapvetóen narratív lény. Az ember az életet történetként, folyamatként fogja fel, benne különböző szereplőkkel, konfliktusokkal, eseményekkel. Fisher szerint a narráció szimbolikus cselekedetek, szavak és/vagy tettek összessége, amelyek sorba rendeződnek és jelentést hordoznak azok számára, akik megélik, létrehozzák és értelmezik azokat. Az értelmünkre ható kommunikáció valamennyi formáját olyan történetként kell felfognunk, amelyet a történelem, a kultúra és a jellem alakít. Minden üzenetet történetként kell felfogni, még akkor is, ha formailag nem az, mert lehetővé teszi számunkra, hogy kiemeljük azokat a részleteket, amelyek a magunk története szempontjából fontosak, és amit a magunk történetébe tudunk illeszteni (Griffin, 2010. 308-310. o.). Az eddig elmondottak párhuzamba állíthatók Bruner narratív gondolkodásról vallott véleményével, különbség abban fedezhető fel, hogy míg Bruner a narratív gondolkodást egy, a paradigmatikus gondolkodást megelőző, egyszerúbb reprezentációs és jelentéstulajdonítási formaként fogta fel, addig Fisher úgy gondolja, hogy a tudományos gondolkodást felülírja az emberek narratívákban való gondolkodása, hiszen az élet tapasztalatainak feldolgozásakor a saját történetük szempontjából értelmezhető adatokat, tényeket fogadják el, függetlenül attól, hogy az nem feltétlenül tudományos elméletalkotás során jött létre. Fisher bevezeti elméletében a racionális világ paradigma és a narratív paradigma fogalmát. A racionális világ paradigmája szerint az ember alapvetően racionális lény, érvek alapján hozza a döntéseket, az érvelés menetét az adott beszédhelyzet típusa határozza meg (pl. jogi, tudományos). A racionalitást a tudásunk és érvelési képességünk 
határozza meg. A világ olyan rejtvényekből áll, amelyeket racionális elemzéssel fel lehet fejteni (Griffin, 2010. 310-311. o.). Fisher úgy gondolja, hogy ez a felfogás erősen korlátozná az emberek mozgásterét, és nem magyarázza meg azt, hogy az emberek bizonyos helyzetekben miért cselekednek a külső szemlélő számára racionálisnak túnő megoldással ellentétesen. A narratív paradigma arra világít rá, hogy az ember alapvetően történetmondó, és a számára helyes érvelés dönt. Azt, hogy az egyén számára mi minősül helyes érvelésnek, az életrajz, a kultúra, az egyedi jellem- és személyiségvonások határozzák meg. A beérkező tapasztalatok megszúrésekor az emberek a narratív koherencia és a narratív hitelesség szempontjait tartják szem előtt, vagyis azt, hogy a számukra minden fontos információt megkaptak-e a történetből (belső következetesség van-e a történetben), illetve, hogy a hallottak mennyire megfeleltethetők előzetes ismereteiknek, élményeiknek, vagyis mennyire integrálható a hallott információ a már kialakított történetükbe. Ily módon az emberek számára saját és mások példaértékû történetei is a meggyőzés forrásaivá válhatnak, a legtöbb vallási hagyomány is a történetek újramesélésén keresztül hagyományozódott hosszú időn keresztül. Érzékelhető, hogy Fisher elmélete hatalmas hangsúlyt helyez a szubjektumra, az önálló történetalkotásra, az önértelmezésre. ${ }^{6}$

\section{Kollektív Emlékezet és szakmai identitásformálás}

Baló József egyik kiemelt célja a Paedagogiai Esetek szerkesztésekor az írások gyakorlati hasznának előtérbe helyezése volt. Több alkalommal is külön cikkben adott útmutatást arra vonatkozóan, hogy melyek lehetnek azok a témák, melyek a rovat tárgyát képezhetik: „De épen azért mert vállalkozásunk zsenge szárából idővel nagyon is megbecsült törzs és korona fejlödhetik, azt kellő belátással és tárgyilagossággal kell fejlesztenünk. Alig van tér, a mely az elburjánosodásnak jobban ki volna téve, mint az, a melyre léptünk, mert a felvételhez minden esemény jogos igényt látszik formálni, a mely bármely nevelői ténykedésnek mozzanata vala... " (Baló, 1889. 153-154. o.). Baló felelősségét érezte annak, hogy egy országos hatókörú pedagógiai folyóirat ne pusztán az embereket jobb kedvre derító, szórakoztató pedagógiai tapasztalatokat és élményeket, hanem olyan pedagógiai eseteket mutasson be, melyek a szakmai fejlődés valamely szempontjából mértékadók. Ez fontos, tekintve, hogy a nyilvános térbe elhelyezett szövegek erőteljes öndefiníciós szereppel bírnak (Keszeg, 2008. 135. o.). Ennek nyomán felmerül a Paedagogiai Esetek kollektív emlékezet tartalmainak kialakításához és a szakmai identitás formálásához kötődő szerepe. Baló iránymutatásai nyomán egyértelmúvé válik, hogy a beérkező esetek közül szelektáltak, fontos tehát tudni azt, hogy mi volt a válogatás és az újságban való közlés szempontrendszere.

\footnotetext{
${ }^{6}$ Bár többen vitatták Fisher elméletének széleskörú alkalmazhatóságát (ld. Griffin, 2010. 315. o.), felveti azt az igen fontos kérdést, hogy a tudományos gondolkodás uralta világban valóban a ráció-e az úr, vagy azt felülírhatja az emberi tapasztalatok és az önértelmezés folyamatossága.
} 
A tények megszúrése és újraértelmezése a nem tudatosan formált emlékezet velejárója is, tulajdonképpen a felelevenítés természetéből fakadó sajátosság. Az emlékezés kulturális és társadalmi keretfeltételek dolga, egy adott közösség vonatkoztatási kereteitôl függ az, hogy tagjai mire és hogyan emlékeznek (Halbwachs, 1925/1971, 1949/2000). A társadalmak, a társadalmon belüli csoportok olyan módon is formálják az önelképzelésüket és teszik folytonossá az identitásukat nemzedékeken át, hogy kialakítják az emlékezés kultúráját. A közösségek kiválasztják azt, hogy mire és hogyan szeretnének emlékezni. Adott csoport dönti el, hogy mit szükséges megtartani és mi az, ami kevésbé fontos. „Ami az egyes individuumokat »mi-vé« kovácsolja, az nem más, mint a közös tudás és önelképzelés konnektív struktúrája, amely egyfelől közös szabályokra és értékekre, másfelől a közösen lakott múlt emlékeire támaszkodik" (Assmann, 1999. 16. o.). Baló úgy gondolta, hogy a Paedagogiai Esetek egyfajta tér és idő feletti szakmai múhelyként funkcionál majd,vesszőt tettem és erőteljes mintaadó szerepe lesz: „Ilyen szempontok tekintetbe vételével erősen hiszem vállalatunk sikerét, így mühelylyé válik vállalatunk. Melyben alapos rendszer készül, s mely évek hosszú sora után írókat fog provocalni a gyakorlati nevelés elméletének megírására, s addig jó nevelöi jellemeket fog fejleszteni" (Baló, 1889. 153-154. o.). Ennek nyomán a Paedagogiai Esetek értelmezhető a kulturális emlékezet hordozójaként, mivel tudatosan szelektált tartalmakat közvetített, és szerepet vállalt a tanítóság szakmásodási folyamataiban. Különösen érdekes kérdés lehet az, hogy a kollektív szakmai emlékezet fórumaként a lap a tanítók napi gyakorlatának mely mozzanatait jeleníti meg, mely momentumait őrzi meg igazodási pontként, mindeközben értékítéletet alkotva arról, hogy mi az, ami mintaadásra alkalmas lehet és mi az, ami nem.

\section{A „TANÍTÓI MESÉK” NYOMÁBAN}

\section{A pedagógiai esetek formai és tartalmi sajátosságairól}

A Paeadagogiai Esetek indulását követően azonnal a lap állandó rovatává vált, szinte minden számban jelent meg legalább egy eset, de volt rá példa, hogy akár három-négy rövidebb szöveg is helyet kapott a rovatban. Az esetleírások terjedelme igen változó volt, egyaránt jelentek meg a pársoros (6-8 soros) és az akár több oldalnyi terjedelmú szövegek is. A vizsgált időszakban 322 darab történetet közölt a lap, közel 60 szerző közremúködésével.

Tematikájukat tekintve a szövegek igen sokszínúnek mondhatók, ugyanakkor nagyfokú ismétlődés figyelhető meg a témafelvetéseket illetően. Ez az ismétlődés mutatja meg igazán azon fontosabb problématerületeket, melyek az adott időszakban megoldandó feladatként jelentkeztek a „mindennapok tanítója”, a szakmai közösség, a neveléstudomány és az oktatáspolitika számára. A rovat gyakori témái a következők voltak:

- a tankötelezettség teljesítése (hiányzások, mulasztások, iskolával kapcsolatos 
szülői attitûdök);

- a családi és az iskolai nevelés hatásköre (együttmúködés, kompromisszum, konfrontáció);

- a család nyújtotta magatartási és viselkedési mintákkal kapcsolatos tapasztalatok, problémák (viselkedés, szóhasználat, higiénia stb.);

- a családi nevelés jellemző sajátosságai (következetesség a nevelésben, büntetés, jutalmazás, számonkérés stb.);

- az erkölcsi nevelés gyakorlati megvalósulása az iskolában (jellemző problématípusok: lopás, hazugság, szófogadatlanság);

- családi diszfunkciók hatásai (veszélyeztető környezet, elhanyagolás, agresszió, bántalmazás, alkoholizmus);

- az oktatás módszerei;

- a tanítók megfigyelései tanulóik jellemfejlődésével kapcsolatosan;

- jutalmazás és büntetés az iskolában.

A témafelvetések sokszínúsége mellett megjelent a vélemények, tapasztalatok, helyzetértékelések sokfélesége is; többnyire differenciált látásmód érvényesült egy-egy tipikus problémakör kapcsán. A szerkesztői éleslátás (a szövegválogatást illetően) is segíthette azt, hogy a közölt pedagógiai esetek párbeszédbe léptek egymással, újabb és újabb szempontokat behozva egy téma tárgyalásánál. Például, ha a családi nevelésről esett szó, a hiányosságokat taglaló szövegek ${ }^{7}$ mellett megjelentek az olyan esetleírások is, melyek a gondos, körültekintő szülői magatartás érdemeit tárgyalták. Az iskolai mulasztások kapcsán pedig a háttérokok számbavételének széles skálája bontakozott ki, felvetve szülő és tanító felelősségét egyaránt ${ }^{8}$. Az egy-egy témához kapcsolódó esetleírások már csak sokféleségüknél fogva is alkalmasak voltak arra, hogy elgondolkodtassák az olvasót, új értelmezési szempontokat kínáljanak fel nekik, mérlegelésre, körültekintőbb információgyứjtésre sarkallják őket. Fenti megfigyeléseimet az iskolai jutalomosztás problematikája kapcsán szeretném gyakorlati példákkal szemléltetni. Függetlenül attól, hogy a közölt esetek elsősorban a tanítók narratívái, tehát a tanítókon „átszúrve” jelennek meg az események elbeszélései, lehetőséget nyújtanak arra, hogy - áttételesen ugyan, de - a szülők és a gyermekek gondolkodásmódjáról, attitúdjeiről is képet kapjunk.

Az iskolai jutalomosztásról - a beküldött esetek alapján - elmondható, hogy visszatérő problématerületként jelent meg a hétköznapokban. Újabb terepet

\footnotetext{
${ }^{7}$ A szülői nevelési eljárással, módszerekkel kapcsolatos bírálatok megjelennek például az alábbi pedagógiai esetekben: 16. A hiányos házi nevelés; 20. Drasticus apai dressura; 22. Egy krajczár története; 54. Az ellopott kenyér története; 58. Babona; 61. A kinek a szülők pártját fogják. A családi nevelés eljárásait, módszereit, érdemeit értékelő pedagógiai esetek például: 9. A magántanítás előnye; 59. Az élet és az iskola; 99. Adoma; 149. A gyermek első megjelenése az iskolában.Fontos megjegyezni, hogy mennyiségileg nem azonos mértékben jelentek meg a szülőket bíráló, és érdemeikre figyelmet felhívó cikkek; előbbire lényegesen több példát találunk.

${ }^{8}$ Példák az iskolakerülésre, mulasztásra reflektáló pedagógiai esetekre: 49 . A mulasztott óra igazolása; 90. Az elengedés; 95. Mulasztások igazolása; 100. A hanyag tanító; 105. Kitől tanulta a gyermek a hazugságot?; 142. Az ajándék; 155. Ruhája zár van; 169. A mulasztás valódi oka;
} 
nyújtott a szülőkkel való konfrontálódáshoz és a gyermeki lélek érzékeny egyensúlyának veszélyeztetéséhez is.

Ha a szülői attitúdöket vizsgáljuk, megjelent - többek között - a gyermekéért aggódó szülő képe: „Fiamnak minden tárgyból egyese van s jutalmat még sem kapott. (... ) Ez annyira elszomorította a fiamat, hogy ma 3-ad napja már a jutalom kiosztásának s mégis mindegyre emlegeti az igazságtalanságot. Tessék, megmondani, hogy lehet az, hogy jutalmazásnál így intézkednek?"9 Az érdekét érvényesíteni kívánó, követelőző szülő képe: „Szomorú, mert a tanulók szülői míg egyfelől a kegyes adakozó iránt, egy kevés kivétellel, semmi elismeréssel nem voltak, másfelől a tanitókat azzal vádolták, hogy igazságtalanúl osztották ki a jutalmakat. Némely szülő a jutalom kiosztása után rögtön azt panaszolta a másiknak, hogy az ő gyermeke is felelt oly jól vizsgálaton, mint a másiké, és mégis kevesebb jutalmat kapott." 10 A gyermekéért mindenáron tenni akaró szülő képe: „Tanító úr monda, hogy fiam jól tanúl (...) Szeretném, ha jutalmat kapna. Akkor jobban igyekeznék. Hoztam egy tallért édes tanító úr legyen szíves adja ki neki az exámen végén úgy, mintha az iskola adná (...) A tallért nem fogadtam el. (...) A fiú nem kapott jutalmat a vizsgálaton. (...) A jobbak kaptak. Vendégem jó ideig görbe szemmel nézett rám."11

Plasztikus, neveléslélektani szempontból fontos megfigyelések jelentek meg a jutalomosztás gyermekre gyakorolt negatív hatásairól: „Ugyan t. tanító úr, miért nem adtak jutalmat a kisleányomnak, hiszen az nem volt rossz tanuló (...) Ugy sír szegényke, hogy ő nem kapott jutalmat. Felvilágosítottam, hogy szívesen adtam volna gyermekének is, de nem jutott. Az édes anyát, mikor gyermeke javáról van szó, ritkán lehet meggyozzni."12Egy másik esetben ezt olvashatjuk:, $A$ vizsgálatnak vége volt. Jutalomra nehány szegénysorsú tanulót jelölt ki az érdemsorozati napló, a vizsgálat eredménye s a gondnokság (...) egy kis leányka, közepes tanuló, sírva ment panaszra atyjához (...) hogy miként van az, hogy ő most nem kapott jutalmat (...) Gyermekem, szólt megnyutatóan az atya, azok nyomorultak, koldusak, a pénzre szükségök van (...) S. K. egyik megjutalmazott szegénysorsú jó tanuló, hallotta e szavakat. Tallérjait nem nézegette többé, sírva távozott (...) Önérzetét sértették."13 Visszatérô gondolata volt a tanítóknak, hogy a jutalom nem tudja betölteni funkcióját, sőt inkább kártékony volta került előtérbe: „Jutalom-osztás hatásárol collegám így nyilatkozott: "Iskoláink tanulói közül azok, kik jutalmat nem kapnak, a közvizsgálatról úgy mennek haza, mint a temetésről visszatérők. Az iskolának nem lehet czélja, hogy ilyen hatásokat elöidézzen."14

A jutalomosztás ceremóniája sokszor inkább a szakadékot növelte a szülők

\footnotetext{
${ }^{9}$ Székely Árpád (1899): Szomorkodik a miatt, hogy nem kapott jutalmat. 299. Paedagogiai Eset. Család és Iskola, 25. 206.

${ }^{10}$ Boga Károly (1890): Jutalmak kiosztása. 28. Paedagogiai Eset. Család és Iskola, 16. 7. sz. 69.

${ }^{11}$ Ismeretlen szerző (1890): Az apa tallérja. 38. Paedagogiai Eset. Család és Iskola, 16. 12. sz. 123.

${ }^{12}$ Ismeretlen szerző (1890): "Jó könyv" 39. Paedagogiai Eset. Család és Iskola, 16. 12. sz. 123.

${ }^{13}$ Ismeretlen szerző (1890): A jutalom a koldust és nyomorultat illeti. 36. Paedagogiai Eset. Család és Iskola, 16. 12. sz. 122.

${ }^{14}$ Ismeretlen szerző (1890): A jutalom-osztás hatása. 41. Paedagogiai Eset. Család és Iskola, 16. 12. Sz. 123.
} 
és a tanítók között: „Szomorú, mert a tanulók szülői míg egyfelől a kegyes adakozó iránt, egy kevés kivétellel, semmi elismeréssel nem voltak, másfelöl a tanítókat azzal vádolták, hogy igazságtalanúl osztották ki a jutalmakat. (...) Ezen kellemetlenségek arról győztek meg bennünket, hogy a köznép még nem érti a jutalmazás azon czélját, amelyet a kegyes adakozó el akart érni."15

Emellett jelent meg példa a találékony, konstruktív nevelői hozzáállás megnyilvánulására is, az alábbi szövegrészletben egy tanító frappáns, tanulóinak szánt magyarázatát olvashatjuk a jutalomosztás célját illetően: Szabó.

„- Hát én nem kapok jutalmat? szólal meg a mellettem álló tanítványok közül a kis

- Te is kapsz, de majd én adom.

- Hát én kapok? kérdik többen a gyermekek.

- Mindenkinek fogok adni jutalmul egy értesitőt, csak most csendben legyetek.

- Igen, de az értesító nem olyan, mint azok a jutalomkönyvek, melyeket az igazgató úr ad.

- Nem baj, azért mégis jutalom lesz. Abból megtudjuk, hogy hányasa van mindenkinek minden tárgyból, mert belé van nyomtatva."16

A tanítók részéről nagy számban érkeztek olyan írások is, amelyek az önreflexió hangjait tükrözték szakmai gyakorlatukat, eljárásukat illetően: „Egy gyermeknek szülöje megtámadott engemet és tanítótársamat, hogy miért nem kapott lánya jutalmat. "Nem jutott uram, szivesen adtunk volna" "Jól van, más iskolába viszem gyermekemet." E tanévre más iskolába vitte gyermekét, olyanba, hol a vizsgán minden gyermek kap egy kis képet. Azt hiszem, hogy ez az általános jutalmazás inkább megközelíti azt a czélt, melyet a jutalom, melyet a jutalom-osztással elérni akarunk."17 Megjelent a jó és múködő gyakorlatok elsajátítására és azok szakmai közösséggel való megosztására való igény is: "Ugy o, mint a gyakorló iskolának tanára arra kérték az igazgató tanácsost, hogy engedje meg, hogy azt az 5frtot belátásuk szerint használják fel a gyermekek megjutalmazására. (-) Az 5frttal vettek kiflit és cseresznyét. A vizsgálat napján délután a gyermekek felmentek az isk. udvarára, hol játszottak s a kifliből és cseresznyéből mindenik EGYENLŐEN részesült."18

Olykor a rovat szerkesztője az esetek válogatásával szándékosan is ütköztette az egymásnak ellentmondó nézeteket egy-egy kérdés kapcsán, aktívabb párbeszédet alakítva ki így. A vizsgált időszakban több olyan eset is megjelent, ami megmozgatta az olvasótábort és hozzászólásokat generált egy-egy ismertetett nevelői eljárás kapcsán. Volt példa arra is, hogy maga a szerkesztőség kérte az olvasóktól, hogy reflektáljanak egy közölt esetre. Ilyen volt például a 209-es eset, melyben a tanító arról számolt be, hogy egy ellopott korona kapcsán

\footnotetext{
${ }^{15}$ Boga Károly (1890): Jutalmak kiosztása. 28. Paedagogiai Eset. Család és Iskola, 16. 7. sz. 69.

${ }^{16}$ Székely Árpád (1899): Jobban szereti az évi értesítőt, mint a jutalomkönyvet. 288. Paedagogiai Eset. Család és Iskola, 25. 141.

${ }^{17}$ Ismeretlen szerzo (1890): „Más iskolába viszem gyermekemet”. 40. Paedagogiai Eset. Család és Iskola, 16. 12. sz. 123.

${ }^{18}$ Sólyom János (1890): Kifli és cseresznye. 42. Paedagogiai Eset. Család és Iskola, 16. 12. sz. 123.
} 
milyen fondorlatos módon, a diákok babonás hitére alapozva kerítette kézre a tolvajt. A szerkesztőség az alábbi kommentárt fúzte az esethez: „Közzétettük, mert megtörtént, de ezt az eljárást nem hagyhatjuk helybe. Szívesen vesszük, ha valaki megokolja, hogy miért nem volt jó a tanitó eljárása."19

A beküldött pedagógiai esetek nagy érdeme volt, hogy gyakran megjelenítette a szerzők saját módszereikkel, tanítói szerepükkel kapcsolatos (ön)reflexióikat, ezeket a gondolatokat többnyire „tanulság vagy következtetés” címszó alatt foglalták össze. Az alábbi szöveg jól példázza a tanító önmagával szemben megfogalmazott kritikai észrevételeit: „Mivel annakelőtte az emelkedettebb elemi osztályokat egyhuzamban több éven át tanítottam, a kicsinyekkel való bánásmódból sokat felejtettem. Ennek tulajdonitható a következő eset. Egy alkalommal Gábornak, ki ismételten helytelen magaviseletet tanusitott, meglehetös haraggal azt mondtam, hogy ha még egyszer rendetlenkedik, az asztal alá ültetem. Erélyes fellépésemet nyomban megkoronázta egy általános derültség. Haragomban az asztalra csaptam tenyeremmel és szilenczium lett. Megfélemlített tanitványaim az óra hátra levő részében kifogástalanul ültek (...) de szomoruan kelle tapasztalnom, hogy magyarázataimat nem értik, s kérdéseimre még a legtehetségesebb növendék is akadozva felel. Ez esetböl két tanulságot vontam le. Egyik az, hogy kezdö tanuló elött, ha elökészítve nincsenek, némely fegyelmi eszköz nevetségessé válhatik s mint ilyet nem volna okszerü használni. A másik az, hogy haragudni s egyúttal tanítani merö képtelenség."20

Szerkezetüket és nyelvezetüket tekintve is változatosak voltak a rovat esetleírásai. Egyes szövegek egy nézőpontból történő, rövid, tömör történetmesélésre vállalkoztak, vagyis adott helyen és időben történő események egymáshoz illesztésére. Közben más szövegek -kitágítva az elbeszélés idő- és térstruktúráját visszanyúltak a múltba, és tételesen számba vették adott helyzet kialakulásának okait, körülményeit. Ezen írások több nézőpontot ötvözve létrehozták egy, az elbeszélő tanítón átszûrt kisebb közösség narratíváját az adott eseményről (pl. a család és az iskola közös értelmezése egy gyermek jellemfejlődéséről); majd a jövőbe tekintve előrevetítették a várható fejleményeket. Megjelentek olyan szövegek is, melyek szinte teljes egészükben egy-egy diákkal vagy szülővel folytatott párbeszédet modelláltak az élőbeszéd szófordulatait tükrözve. A történetek megjelenítették a szerzők saját praxisbeli tapasztalatait, a kollégáktól hallott tapasztalatok saját szempontú értelmezéseit, és áttételesen megjelentek a szülői narratívák is. A következő leírástípusok, illetve ezek ötvözetei jelentek meg nagy gyakorisággal a rovatban:

- rövid, tömör esetközlés (lineáris történetmesélés, kiegészítő magyarázatok nélkül, tér és idő szempontjából szigorúan egy adott helyzet leírására törekszik);

- több szereplő nézőpontját ötvöző esetközlés (a tér- és időkezelés szabadsága jellemzi; célja: a múlt tapasztalatainak összevetése, összekötése a jelen

\footnotetext{
${ }^{19}$ Bölöni István (1896): Hogy került meg az elveszett korona? 209. Paedagogiai Eset. - Szerkesztőségi hozzászólás. Család és Iskola, 22. 1. sz. 10.

${ }^{20}$ Szentgyörgyi Lajos (1890): Egy kikaczagott fegyelmi eszköz. Család és Iskola, 16. 4. sz. 37.
} 
eseményeivel);

- az elbeszélő tanító korábbi megfigyeléseinek számbavétele egy kialakult problémahelyzethez kötődően (célja például egy tanuló jellemfejlődésének a bemutatása, vagy egy kialakult helyzet előzményeinek a számbavétele);

- pedagógiai tanmese (direkt érvelés; magyarázat nélküli felismertetése valamely pedagógiai jelenségnek, átgondolandó helyzetnek);

- esetközlés és az adott nevelői eljárás szakmai szempontú elemzése;

- esetközlés olyan elemekkel, melyek a mélyebb szakmai önreflexió folyamatának érzékeltetésére alkalmasak.

\section{ÖsSZEGZÉs: (TANÍTÓI) NARRATÍVÁK MINT A (PEDAGÓGIAI) GONDOLKODÁS FORMÁLÁSÁNAK ESZKÖZEI}

A Paedagogiai Esetek címú rovat szövegei többnyire életközeli pillanatképek voltak, melyek a mindennapi tanítói gyakorlat vagy a családi élet terepére kalauzolták az olvasót. A hasábokon gyermeki csínytevések pontos részletei, szülők és tanítók párbeszédei, a hétköznapi élet legapróbb mozzanatai elevenedtek meg,gyakran a történetmesélő (ön)reflexiójának is helyet adva. A történetek a maguk valóságában kívántak eleget tenni Baló József azon fontos célkitúzésének, hogy a gyakorlati pedagógia alapjául szolgáló, a tanítók számára irányadó és jellemfejlesztő esetek tárházává váljanak.

Arra a kérdésre, hogy miért választja a rovat a narratívák, vagyis elbeszélések segítségével történő gondolkodás- és jellemformálást, Bruner elmélete adhat számunkra választ. A narratív készség a nyelvhasználat hajtóereje, a világ dolgai közötti kapcsolatteremtés, az ok-okozati viszonyok megállapítása és az azoknak való jelentéstulajdonítás az emberi gondolkodás egyik alapvető sajátossága. A tanítói narratívák megértése, az abban foglalt összefüggések átlátása tehát nem követelte meg a tudományos gondolkodás magas szintjét a befogadótól. Ez különösen fontos, hiszen a szaklap célközönségének tartotta a szakmásodás útján még bizonytalanabbul lépkedő, magasfokú neveléstudományi ismeretekkel nem rendelkező néptanítók rétegét és a szülőket egyaránt. A dualizmus kora a korszerú neveléstudomány kialakulásának, formálódásának időszakát, a tanítóés tanárképzés (újjá)szervezésének időszakát öleli fel. A tantermi valóság tapasztalatainak közreadása, a gyakorlati megoldások szó szerinti közvetítése, illetve annak vitára bocsátása tehát könnyebben utat találhatott a szakmáról elsősorban saját tapasztalataik és nem a szisztematikus elemzés nyomán gondolkodó nevelőkhöz. A történetek szubjektív hangvétele, az ismerős élethelyzetek felismerése megkönnyíthette az olvasó számára az azonosulást, a szakmai párbeszédbe való bekapcsolódást, a korábbi tapasztalatokkal való összevetést. Ezen jellemzők nagyrészt összecsengenek a szóbeli közlések, produktumok által használt kifejezésmódbeli eszközökkel is.

Tekintettel arra, hogy a Paedagogiai Esetek címú rovat a pedagógiai gya- 
korlatok tárházaként múködött, a beküldött eseteket vizsgálatom során egy szövegkorpuszként értelmeztem, és az eseteket egymáshoz csatolva mintegy összefüggő szöveggyújteményt vizsgálat alá vetettem Walter Ong azon megfigyelési szempontjai mentén is, melyeket a szóbeliségen alapuló gondolkodás és kifejezésmód jellemzőinek leírása során alkalmazott. A szövegkorpusz egészével kapcsolatosan elmondható, hogy a tárgyalt témák szempontjából inkább halmozó szemlélet jelent meg, semmint elemző. A különböző problémahelyzetek újbóli leírása, kifejtése és különböző megoldási módok részletes ismertetése, felsorakoztatása jellemezte többnyire az eseteket, azok szisztematikus rendszerezése, elemzése nem. A szóbeli közlésekhez hasonlóan a szövegek sok redundáns elemet tartalmaztak, ezek főként a mindennapi problémahelyzetek nyomán megjelenő tanítói magatartásmintákhoz, a konfliktuskezelés módozataihoz kötődtek. Ong szerint „a kirografikus és tipografikus kultúrák még a legemberibb dolgokat is képesek távolságtartóan és bizonyos értelemben alaptermészetüktől függetlenítve kezelni" (Ong, 2010. 42-43. o.). Ezzel ellentétben a pedagógiai esetek gyakorlati vonatkozásainak sokszor „,szó szerinti” (pl. nevelő és gyermek közötti párbeszédek modellálása) közlése biztosította azt, hogy bizonyos ismereteket szigorúan a gyakorlatból kiindulva és annak a terepén maradva, az emberi életvilághoz kapcsoltan adtak át. Ezen szövegekre kifejezetten alkalmazható Ong szóbeli kultúrához kötődő megfigyelése, miszerint: „A szóbeli kultúrák a fogalmakat jellemzően szituációfüggő operatív referenciális keretben használják, mely a lehető legkevésbé elvont abban az értelemben, hogy közel marad a megélt emberi világhoz (...) a tanulás és a megismerés nem mást jelent, mint közeli empatikus, közösségi azonosulást, megbarátkozást a megismerés tárgyával." (Ong, 2010. 49. o.). Jelen esetben az írás nem választja el egymástól a megismerés tárgyát és alanyát, nem kényszerít rájuk távolságtartást. Ennek nyomán múködésbe léphet a Fisher által bevezetett narratív koherencia és hitelesség mechanizmusa is, vagyis, ha a befogadó egy olyan, saját életvilágához közeli narratívát olvas, amiben a számára fontos információkat megtalálja és azokat a saját tapasztalataihoz tudja illeszteni, akkor hitelesnek ítéli meg a történetet, és annak elemeit, tapasztalatait beépíti saját „történetébe”, értelmezésébe, végső soron pedig szakmai repertoárjába.

A tanítói narratívák pedagógiai sajtóban való közreadása azért is különösen érdekes, mert egyrészt előtérbe kerülnek az individuális nézőpontok a szubjektív történetek révén, másrészről azonban a megjelenés helye egy szaklap, melynek szerkesztését egy, a szakmai gondolkodást formálni kívánó közösség végzi. Baló József alapvető célkitûzése volt, hogy a narratívák a szakmai közösség üzenetét is hordozzák valamilyen formában, és egy kollektív szakmai tudástár álljon össze belőlük. A korábban bemutatott 209-es eset példája arra enged következtetni, hogy a szerkesztőség nem, vagy csak kevéssé módosította a beküldött szövegeket, ugyanakkor a nagyon kényes helyzetekben szakmai kommentárt fúzött hozzájuk, mozgósítva az olvasókat az aktív szakmai párbeszédre. A tematikai ismétlődés nyomán pedig látható, hogy a szerkesztőség ráirányította a figyelmet bizonyos problematikus helyzetekre, reflektálva így az oktatásügyről 
- a századforduló környékén - folyó „közbeszéd” legjellemzőbb kérdéseire; formálva ezzel a szakmai gondolkodás, majd a kollektív emlékezet terepét.

Ahhoz, hogy teljesebb képet kapjunk a tanulmányban felvázolt folyamatokról, elengedhetetlen a szövegkorpusz mikroszintú elemzése is. Kutatásom további irányait ez jelöli ki; szükséges az egyes történeteknek - mint személyes narratíváknak - az értelmezése és elemzése, a narráció elemeinek és az ahhoz rendelődő nyelvi mintázatoknak a részletes feltárása. A mikroszintú elemzés értelmezési keretét szélesítheti a Paedagogiai Esetek állandó szerzőinek és a Család és Iskola rendszeres előfizetőinek áthatóbb (vö. Nóbik, 2014) vizsgálata is.

\section{IRODALOMJEGYZÉK}

Assmann, Jan (1999): A kulturális emlékezet. Írás, emlékezés és politikai identitás a korai magaskultúrákban. Atlantisz Könyvkiadó, Budapest.

Baranyai Mária és Keleti Adolf (1937): A magyar nevelésïgyi folyóiratok bibliográfiája 1841-1936. Fóvárosi Pedagógiai Könyvtár Kiadványai 3., Budapest.

Baska Gabriella (1998): A tanítóság hétköznapjai és ünnepei az 1896. év pedagógiai sajtója alapján. In: Bábosik István és Széchy Éva (szerk.): Új tehetségek és kutatási eredmények a hazai neveléstudományban. Pro Educatione Gentis Hungariae Alapítvány, Budapest. 23-31.

Baska Gabriella, Nagy Mária és Szabolcs Éva (2001): Magyar tanító, 1901. Iskolakultúra, Budapest.

Baska Gabriella (2011): Gyermek, iskola és tanitói ideál a 19. és 20. század fordulóján. Gondolat Kiadói Kör Kft., Budapest.

Baska Gabriella és Szabolcs Éva (2005): Életreform-motívumok a Népmúvelés (Új Élet) címú folyóiratban 1906-1918. Iskolakultúra, 15. 2. sz. 5-11.

Baska (2018): "Néptanítónak lenni nem comicum". A Borsszem Jankó tanítóképe. In: Fehérvári Anikó (szerk.): A Borsszem Jankótól Bolognáig. ELTE PPK L'Harmattan Kiadó, Budapest. 13-32.

Bruner M., Edward(1989): Az etnográfia mint narratíva. In: N. Kovács Tímea (1999, szerk.): Narratívák 3. A kultúra narratívái. Kijárat Kiadó, Budapest.

Bruner, Jerome (1986): Actual minds, possible words. Cambridge, Mass., Harvard University Press

Donald, Merlin (2001): Az emberi gondolkodás eredete. Osiris, Budapest.

Fulda, Daniel (2014): Historiographic Narration. Letöltés: https://www.1hn. uni-hamburg.de/node/123.html, 2018. 10. 16.

Golnhofer Erzsébet és Szabolcs Éva (2009): Iskola és történeti emlékezet. Gondolat Kiadó, Budapest.

Griffin, Emory (2012): A first look at Communication theory. McGraw-Hill, Inc., New York. 
Gyáni Gábor (2000): Emlékezés, emlékezet és történelem elbeszélése. Napvilág Kiadó, Budapest.

Halbwachs, Maurice (1925/1971): Az emlékezet társadalmi keretei. In: Ferge Zsuzsa (szerk.): Francia szociológia. Válogatás. KJK, Budapest. 124-132.

Halbwachs, Maurice (1949/2000): A kollektív emlékezet. III. fejezet. A kollektív emlékezet és az idő. In: Felkai Gábor, Némedi Dénes és Somlai Péter (szerk.): Szociológiai irányzatok a XX. század elejéig. Új Mandátum Kiadó, Budapest.

Hegedûs Judit (2003): Tanítónői karriertörténetek a dualizmus korában. Iskolakultúra, 13. 3. sz. 42-52.

Kelemen Elemér (2002): A magyarországi népoktatás a dualizmus korában. In uő: Hagyomány és korszerúség. Oktatáspolitika a 19-20. századi Magyarországon. Budapest, Oktatáskutató Intézet. Új Mandátum. 121-134.

Kelemen Elemér (2007): A tanító a történelem sodrában. Iskolakultúra könyvek, Pécs.

Keszeg Vilmos (2008): Alfabetizáció, irásszokások, populáris írásbeliség. Kriza János Néprajzi Társaság, Kolozsvár.

Kolosai Nedda (2013): Kisiskoláskor és történeti idő. Az 1950-es évek kisiskoláskorára vonatkozó narratívák elemzése. Eötvös Loránd Tudományegyetem, Budapest. PhD-disszertáció. Letöltés: https ://docplayer.hu/113714366-Kol osai-nedda-kisiskolaskor-es-torteneti-ido-az-1950-es-evek-kisisk olaskorara-vonatkozo-narrativak-tartalomelemzese-doktori-disszerta cio.html 2019. 12. 15.

Méreg Martin (2013): Tanítóképzés és a tanári pálya emlékezete: Egy pécsi tanítóképző intézeti tanár önéletírásának értelmezési lehetőségei. In: Méreg Martin, Somodi Imre és Vörös Katalin (szerk.): Tanulmányok a neveléstörténet pécsi mühelyéből. PTE BTK. Oktatás és Társadalom - Neveléstudományi Doktori Iskola, Pécs. 36-54.

N. Kovács Tímea (1999): A kultúra narratívái. Narratívák a kultúráról. In: N. Kovács Tímea (szerk.): Narratívák 3. A kultúra narratívái. Kijárat Kiadó, Budapest. 7-19.

Németh András (2000): Nemzetközi tudományfejlődési és recepciós tendenciák a század első hazai pedagógiai lexikonjaiban. Magyar Pedagógia, 100. 2. sz. 187-207.

Németh András (2005): A magyar pedagógus professzió kialakulásának előtörténete - a 18. században és a 19. század első felében. Pedagógusképzés, 3. 1. sz. 17-31.

Németh András (2007): A modern középiskolai tanári és tanítói szakmai tudástartalmak kibontakozásának történeti folyamatai. Pedagógusképzés, 5. 1-2. sz. 5-25.

Németh András (2008): A néptanítói tudás konstrukciója Az elemi népoktatás enciklopédiájában (1911-1915). Iskolakultúra, 18. 5-6. sz. 86-102. 
Németh András (2009): A magyar középiskolai tanárképzés és szakmai professzió kialakulása a 18-20. században. Educatio, 18. 3. sz. 279-289.

Németh András (2012): Magyar pedagógusképzés és pedagógus szakmai tudásformák I. 1775-1945. Nemzeti fejlödési trendek, nemzetközi recepciós hatások. ELTE EÖTVÖS KIADÓ, Budapest.

Németh András (2013): A néptanítói szakismeretek konstrukciós folyamatai a 20. század elején a Néptanítók Enciklopédiája alapán (1911-1915). Magyar Pedagógia, 113. 2. sz. 101-118.

Nóbik Attila (2002): Gyermekek a dualizmus iskolái és a család hatókörében. Iskolakultúra, 12. 3.sz.16-19. Letöltés: http://epa.oszk.hu/00000/00011/0005 8/pdf/iskolakultura_EPA00011_2002_03_016-020.pdf.

Nóbik Attila (2006): Népiskolai tanítóság a 19. századi neveléstörténeti tankönyvek tükrében. Iskolakultúra, 16. 4. sz. 41-48.

Nóbik Attila (2014): A dualizmus-kori pedagógiai közélet jellemzői a Család és Iskola példáján. In: Fizel Natasa és Nóbik Attila (szerk.): Ünnepi tanulmányok a 60 éves Pukánszky Béla tiszteletére. Szegedi Egyetemi Kiadó. Juhász Gyula Felsőoktatási Kiadó, Szeged. 189-207. Letöltés: http: //mek . oszk . hu/15000/15 023/15023.pdf 2018.12.05.

Nóbik Attila (2019): A pedagógiai szaksajtó és a néptanitói szakmásodás a dualizmus korában. Szegedi Egyetemi Kiadó; Juhász Gyula Felsőoktatási Kiadó, Szeged. Letöltés: http://publicatio.bibl.u-szeged.hu/17371/, 2020.01.24.

Ong, Walter (2010): Szóbeliség és írásbeliség. Gondolat, Budapest.

Pethő László (1991): Tanítók és a társadalom. Edukáció Kiadó, Budapest.

Pirka Veronika (2010): Az életreform „megmentés” motívumának megjelenése a 20. század eleji magyar pedagógiai sajtóban, a Népmúvelés példája alapján. Iskolakultúra, 20. 7-8. sz. 3-14.

Pukánszky Béla (1999): Utazás a szobában: Gyermeküket tanító apák a XIX. században. Magyar Pedagógia, 99. 1. sz. 97-106.

Pukánszky Béla (2001): Felméri Lajos ismeretlen arca - a gyermekkép újszerú vonásai az elsô kolozsvári pedagógiaprofesszor írásaiban. In: Csapó Benő és Vidákovich Tibor (szerk.): Neveléstudomány az ezredfordulón. Nemzeti Tankönyvkiadó, Budapest. 423-432.

Pukánszky Béla (2002): Gyermeküket tanító apák a 19. század pedagógiai irodalmában. Iskolakultúra, 12. 3. sz. 5-15.

Pukánszky Béla (2005): A gyermek a 19. századi magyar neveléstani kézikönyvekben. Iskolakultúra Könyvek, Pécs.

Szabolcs Éva és Mann Miklós (1997): Közoktatási törvényeink és a pedagógiai sajtó 1867-1944, ELTE, BTK, Neveléstudományi Tanszék, Pro Educatione Gentis Hungariae Alapítvány, Budapest.

Szabolcs Éva (1999): Tartalomelemzés a gyermekkép történeti kutatásában. Gyermekkép Magyarországon 1867-1890. Tankönyvkiadó, Budapest.

Szabolcs Éva (2001): A gyermektanulmányi és reformpedagógiai szemléletmód megjelenése a magyar pedagógiai sajtóban 1890-1906. In: Szabolcs Éva 
és Mann Miklós (szerk.): Magyar Neveléstörténeti tanulmányok I. Eötvös József Könyvkiadó, Budapest. 40-55.

Szabolcs Éva (2002): A gyermektanulmányi szemléletmód megjelenése a Magyar Pedagógiai sajtóban. Iskolakultúra, 12. 3. sz. 33-38.

Szabolcs Éva (2003): Néptanítói álláshirdetések 1901-ből. Kutatásmódszertani megfontolások. Iskolakultúra, 13. 3. sz. 39-42.

Szabolcs Éva és Hegedûs Judit (2008): A gyermekről való gondolkodás differenciálódása a dualizmus korában. Iskolakultúra, 18. 5-6. sz. 77-85.

Szabolcs Éva (2009): Az iskolás gyermekkel kapcsolatos nézetek, elvárások a pedagógiai sajtó elemzése alapján 1868-1906. In: Szabolcs Éva (szerk.): Ifjúkorok, gyermekvilágok II. Eötvös József Könyvkiadó, Budapest. 11-43.

Szabolcs Éva (2011): A gyermekből tanuló. Az iskolás gyermek, 1868-1906. Gondolat Kiadó, Budapest.

Szabolcs Éva (2016): Narratíva és pedagógiatörténet. Egy lehetséges kutatási szemléletmód margójára. In: Garai Imre, Vincze Beatrix és Szabó Zoltán András (szerk.): Hiteles pedagógia: Tanulmányok Golnhofer Erzsébet tiszteletére. ELTE Eötvös Kiadó, Budapest. 79-83.

Szúcs Katalin (2012): A gyászjelentések pedagógiai vetületei. In: Kozma Tamás és Perjés István (szerk.): Új kutatások a neveléstudományokban. Közoktatás, pedagógusképzés, neveléstudomány. A múlt értékei és a jövő kihívásai. ELTE Eötvös Kiadó, Budapest. 155-173.

White, Hayden (1975): Metahistory. The historical imagination in nineteenthcentury Europe. The John Hopkins University Press, Baltimore-London.

White, Hayden (1997): A történelem terhe. Osiris, Budapest.

\section{FELHASZNÁLT FORRÁSOK}

Baló József (1889): Egy kis elmélet a pedagogiai esetek gyújtéséhez. Család és Iskola, 15. 16. sz. 153-154.

Baló József (1890): A paed. esetek körének kibővítése. Család és Iskola, 16. 1. sz. 7.

Boga Károly (1890): Jutalmak kiosztása. 28. Paedagogiai Eset. Család és Iskola, 16. 7. sz. 69.

Bölöni István (1896): Hogy került meg az elveszett korona? 209. Paedagogiai Eset. - Szerkesztőségi hozzászólás. Család és Iskola, 22. 1. sz. 10.

Szerkesztőségi közlemény (1875): Lapunk Czélja. Család és Iskola, 1. 1. sz. $1-2$.

Sólyom János (1890): Kifli és cseresznye. 42. Paedagogiai Eset. Család és Iskola, 16. 12. sz. 123.

Szentgyörgyi Lajos (1890): Egy kikaczagott fegyelmi eszköz. Család és Iskola, 16. 4 . sz. 37.

Székely Árpád (1899): Szomorkodik a miatt, hogy nem kapott jutalmat. 299. Paedagogiai Eset. Család és Iskola, 25. 206. 
Pedagógiatörténeti Szemle • 3. évf. 3-4. sz. 45-66. o. • 2018

Székely Árpád (1899): Jobban szereti az évi értesítőt, mint a jutalomkönyvet. 288. Paedagogiai Eset. Család és Iskola, 25. 141.

Ismeretlen szerző (1890): Az apa tallérja. 38. Paedagogiai Eset. Család és Iskola, 16. 12. sz. 123. o.

Ismeretlen szerző (1890): „Jó könyv" 39. Paedagogiai Eset. Család és Iskola, 16. 12. sz. 123. o.

Ismeretlen szerző (1890): A jutalom a koldust és nyomorultat ilelti. 36. Paedagogiai Eset. Család és Iskola, 16. 12. sz. 122. o.

Ismeretlen szerző (1890): A jutalom-osztás hatása. 41. Paedagogiai Eset. Család és Iskola, 16. 12. sz. 123. o.

Ismeretlen szerzo (1890): „Más iskolába viszem gyermekemet”. 40. Paedagogiai Eset. Család és Iskola, 16. 12. sz. 123. o. 